\title{
Фінансування Міністерства оборони України як фактор впливу на систему ресурсного забезпечення потреб оборони
}

\author{
Євгеній Волков ${ }^{1}$ А; Анатолій Лойшин 2 А

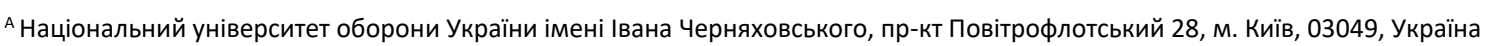

Received: April 10, 2021 | Revised: April 28, 2021 | Accepted: April 30, 2021

DOI: $10.33445 /$ sds.2021.11.2.17

\begin{abstract}
Анотація
Результати дослідження викликають цікавість у науковців та управлінців, які обіймаються проблематикою всебічного забезпечення потреб оборони України. В умовах збройної агресії Російської Федерації на сході України та тимчасової анексії АР Крим забезпечення нагальних потреб оборони України $€$ найвищим пріоритетом державної політики. Інтеграція України у Європейський простір та намагання набути довгоочікуваного членства в НАТО потребує перегляду та удосконалення механізмів забезпечення національної безпеки України, у тому числі, ресурсного забезпечення. Ключовим питанням статті $\epsilon$ здійснення аналізу динаміки видатків з державного бюджету на потреби Міністерства оборони України в умовах триваючої агресії з боку РФ та напрями їх використання. Невід'ємним аспектом в процесі вивчення даної тематики став аналіз витрат на розвиток, закупівлю, модернізацію та ремонт озброєння, військової техніки, засобів, обладнання та динаміки обсягів видатків на утримання Збройних Сил України. Наведено динаміку показників номінального ВВП до потреби оборонних видатків. Запропоновані мінімальні кроки для удосконалення існуючого механізму фінансового забезпечення потреб оборонного, оборонно-промислового комплексу, створення ефективної системи управління в кризовий період. Проведений у статті аналіз дозволив ідентифікувати наявні прогалини бюджетного процесу, що проявляються за рахунок нестабільно орієнтовних показників видатків, мінливості затверджених планів асигнувань, до яких вносяться постійні зміни. Підтверджена необхідність у розподілі видатків на потреби відповідно до найкращих світових практик. Ключовим питанням у контексті проблематики дослідження виділено тривалу економічну та політичну кризу та наявність тривалої боротьби 3 корупцією.
\end{abstract}

Ключові слова: державний бюджет, видатки на оборону, фінансове забезпечення потреб Збройних Сил України, озброєння та військова техніка.

\section{Постановка проблеми}

Вивчення проблематики сектору безпеки і оборони в умовах ведення збройної боротьби є одним із найголовніших завдань у сфері державного управління. Ідентифікація слабких місць та прогалин у функціонуванні систем забезпечення потреб оборони дозволить визначити напрями вдосконалення існуючих підвищити державних адаптувати забезпечення. Набуття визначених у ході оборонного планування спроможностей військ (сил) безумовно залежить від ефективного, належного, своєчасного фінансового забезпечення.

\footnotetext{
${ }^{1}$ Corresponding author: начальник навчальної лабораторії, e-mail: evgeniyvolkov2231@gmail.com

2 доктор філософії, старший викладач кафедри економіки та фінансового забезпечення, e-mail: aloishyn@gmail.com, ORCID: 0000-0003-2769-9336
} 


\section{Аналіз останніх досліджень та публікацій}

Питання фінансового забезпечення розвитку 3бройних Сил України (далі - 3С України) висвітлені у працях таких науковців, як П. Горбулін, Г. Руденська, А. Наливайко, П. Крикун, Р. Бойко, О. Семененко, В. Бойко, О. Левчук [1-9]. Проблематику сучасного реформування системи національної безпеки й оборони досліджують вчені Національного університету оборони України імені Івана Черняховського, Національного інституту стратегічних досліджень при Президентові України та інших навчальних закладах та наукових установах України. В цих роботах обгрунтовано шляхи реалізації реформи національної безпеки й оборони та заходи, які необхідно здійснити у цій сфері.

\section{Постановка завдання}

Метою дослідження $є$ здійснення аналізу динаміки видатків з державного бюджету на потреби Міністерства оборони України в умовах триваючої агресії 3 боку РФ та напрями їх використання.

\section{Виклад основного матеріалу}

Приведення військово-економічних можливостей до необхідних військових спроможностей відбувається на основі функціонування ланки формування бюджету на оборону, яка в свою чергу забезпечує використання бюджетних коштів на виробництво озброєння та військової техніки. Військова міць з одної сторони, відповідає на економічні можливості держави, 3 іншої умовам ведення сучасної (гібридної) війни. Проблеми реалізації військового потенціалу (спроможностей) залежить від ефективного та належного фінансового забезпечення.

Так, відповідно до Указу Президента України “Про Концепцію розвитку сектору безпеки і оборони України" видатки державного бюджету на сектор безпеки і оборони має становити не менше 5\% від показника валового внутрішнього продукту країни (далі - ВВП). Зокрема видатки безпосередньо на оборону - не менше 3 відсотків ВВП щороку, а на забезпечення розвитку оборонно-промислового комплексу - 0,5 відповідно [10]. Законом України “Про Державний бюджет України на 2021 рік" оборонні видатки передбачено у сумі 267,3 млрд. грн, що становить 5,93\% ВВП. Однак, безпосереднє фінансування Збройних Сил України (далі-ЗС України) визначено на рівні лише 116 305,8 млрд. грн [11].

3 огляду на викладену динаміку фінансування Міністерства оборони України (далі- МО України) у 2014-2021 роках (Рис. 1), спостерігається тенденція щодо збільшення обсягів фінансового забезпечення потреб Мо України. Зазначене неодмінно пов'язано із збройною агресією на сході України. Це безумовно потребує залучення додаткових фінансових ресурсів та ідентифікації додаткових джерел фінансування для ефективного відбиття збройної агресії та підтримання у боєздатному стані як вітчизняних збройних сил, так і сектору безпеки і оборони в цілому. Щорічні темпи зростання видатків на оборону перевищують темпи збільшення сукупних видатків державного бюджету України, а також ВВП. Сукупні видатки на МО України за період, що підлягав аналізу, зросли у 7,8 разів. У 2015 році спостерігається суттєве збільшення видатків на оборону, що пояснюється веденням активних бойових дій, проведенням організаційних заходів по удосконаленню структури складових сектору безпеки та оборони, збільшення їх чисельності. Так, у 2015 р. видатки на оборону зросли майже удвічі, порівняно з попереднім роком, при збільшенні сукупних видатків державного бюджету на 34,1\%; у 2017 р. видатки на оборону зросли на $25,1 \%$, а в 2018 р. - на 30,6\% відповідно, у порівнянні із попередніми роками.

Загалом у бюджеті на 2019 рік заплановано понад 103 013,2 млрд грн. для 
МО України, що є на $18 \%$ більше, ніж у 2018 році. Стрімке зростання видатків для забезпечення потреб оборони зумовлене не лише потребою забезпечення відбиття збройної агресії, а й розумінням керівництва держави про необхідність поступової реорганізації сектору безпеки і оборони у відповідності до найкращих світових практик.

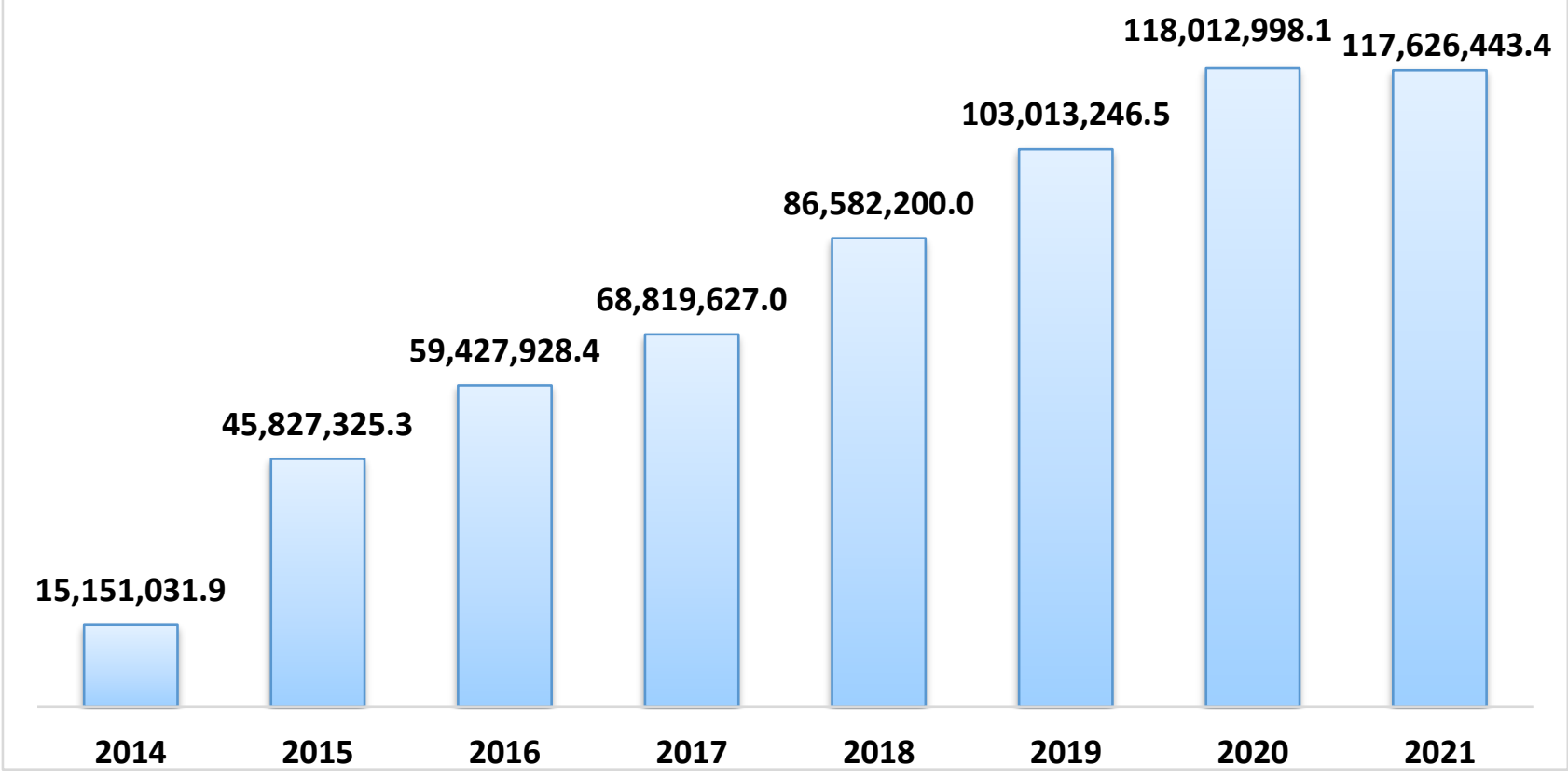

Рис.1. Динаміка планових видатків на потреби Міністерства оборони України у 2014-2021 роках (тис. грн) [11-18].

У 2021 році розмір фінансового ресурсу передбаченого безпосередньо на оборону досягнув показника 2,6\% від ВВП України.

Слід зазначити, що збільшення видатків на оборону $€$ загальносвітовою тенденцією.
Так, рекомендовані Північноатлантичним альянсом витрати на оборону у країнах-членах НАТО мають бути на рівні 2\% від ВВП країни.

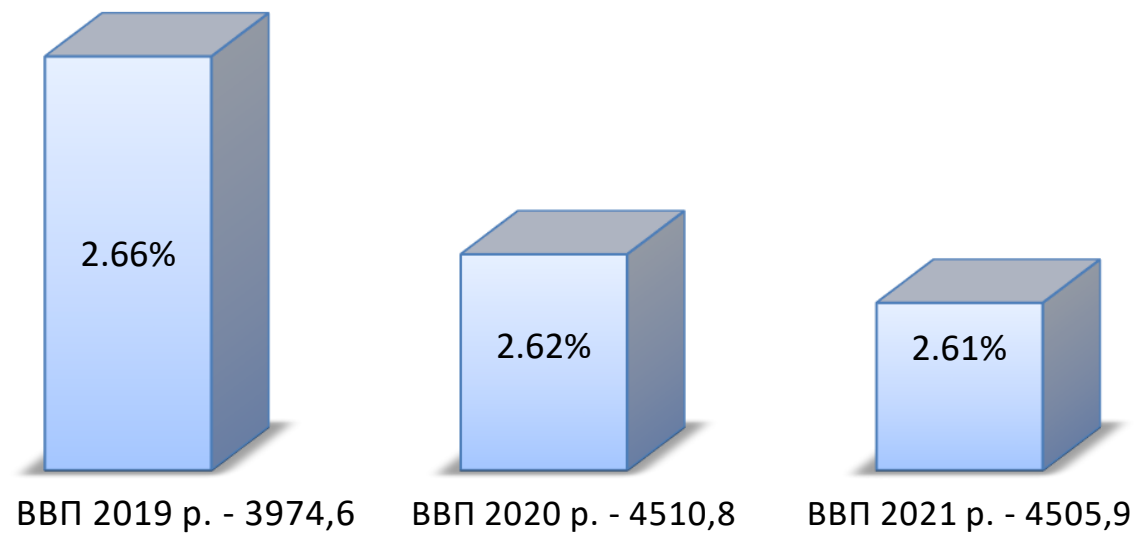

Рис. 2. Відсоток від суми номінального ВВП на потреби Збройних Сил України, 2019-2021 рр. (трлн. грн) [11, 17, 18]. 
Лідерами серед країн-членів НАТО у 2020 року за показником залишалися США - 3,73 відсотка від ВВП. Показник що сягнув двох відсотків від ВВП в 2020 році досягли також Греція $(2,68)$, Естонія $(2,33)$, Великобританія $(2,32)$, Польща $(2,31)$, Латвія $(2,27)$, Литва $(2,13)$, Румунія $(2,07)$, Франція $(2,04)$, Норвегія $(2,0)$ та Словаччина $(2,0)[19]$.

Веб-ресурс Global Firepower за оцінками експертів у 2021 оприлюднив рейтинг щодо військової потужності кожної країни світу. У своїх дослідженнях експерти Global Firepower оцінювали країни за 55-ма показниками. Під порівняння охоплено:

чисельність кадрового складу армій і їі резерву;

кількість різних видів озброєння, які забезпечують оптимальний баланс бойового ураження (літаки і гелікоптери, військові кораблі, танки, артилерія, інша військова техніка), а також інші фактори, що впливають на боєздатність армії (географічне положення, доступ до природних ресурсів, логістика, фінанси). Відповідно до рейтингу найсильніших військових держав світу Україна посіла 25 сходинку зі 140 [20].

Ключовим компонентом військової могутності країни $€$ стан економіки, людські ресурси, та можливості обороннопромислового комплексу (далі -ОПК). Воєнно-політичне керівництво більшості промислово розвинутих країн розглядають ОПк як важливу складову стратегії національної безпеки та оборони країни і приділяють значну увагу захисту важливих i ефективно працюючих підприємств i організацій оборонної промисловості. В структурі ОПК сконцентровані значні інтелектуальні, виробничо-технічні та кваліфіковані людські ресурси, зберігається високий експортний потенціал, що забезпечує надходження до державного бюджету значних коштів [21].

Динаміка фінансування на розвиток, закупівлю, модернізацію та ремонт озброєння, військової техніки, засобів та обладнання виглядає так:

$22735321,0 \quad 22742438,5$

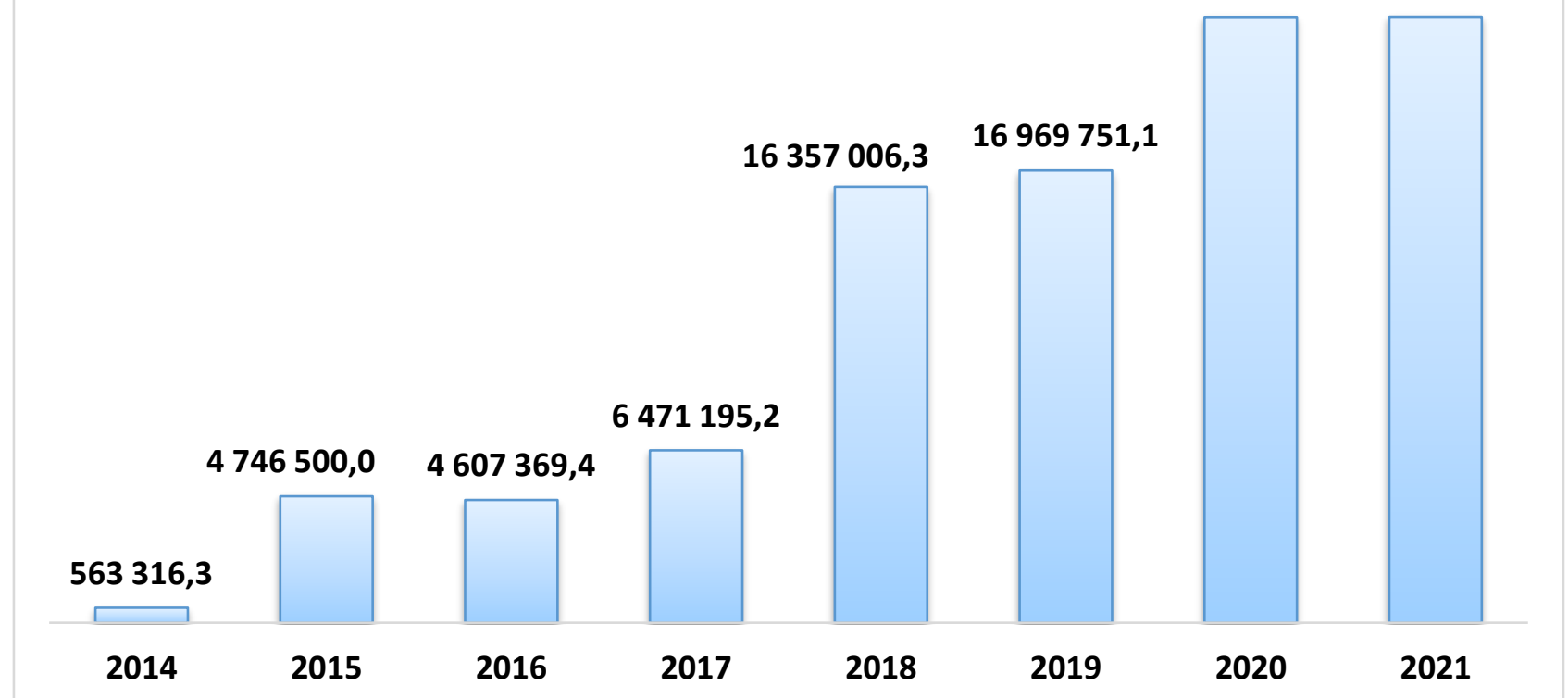

Рис. 3. Динаміка планових видатків на розвиток закупівлю, модернізацію та ремонт озброєння військової техніки 2014-2021 роках (тис. грн) [11-18]

Протягом 2014 - 2021 років на розвиток, закупівлю, модернізацію та ремонт озброєння, військової техніки, засобів та обладнання (далі ОВТ) видатки становили від $14,7 \%$ до 19,4\% від загального бюджету на потреби МО України. Це дає змогу зробити висновок, що основними реальними шляхами підтримання їх у боєздатному стані в основному залишаються поетапна модернізація як основний курс, спрямований 
на розширення можливостей виготовлення та удосконалення ОВТ підприємствами й організаціями вітчизняного ОПК. Світовий досвід показує, що шляхом модернізації тактико-технічні характеристики значної частини ОВТ можуть бути доведені до сучасного рівня, а фінансові витрати зменшені у декілька разів. У багатьох країнах модернізація розглядається як один із основних шляхів технічного забезпечення обороноздатності збройних сил [21]. Нагальна до розв'язання проблема полягає, на додаток у тому, що в структурі видатків на національну безпеку та оборону, видатки розвитку ОВТ і далі розподіляється за залишковим принципом.

Слід зазначити, що у Бюджеті-2020 курс гривні був закладений на рівні 27,5 грн за один американський долар, тоді як у Бюджеті-2021 - 29,1 грн відповідно. Це безумовно буде мати негативні наслідки протягом 2021 року в процесі закупівель військової техніки 3С України.

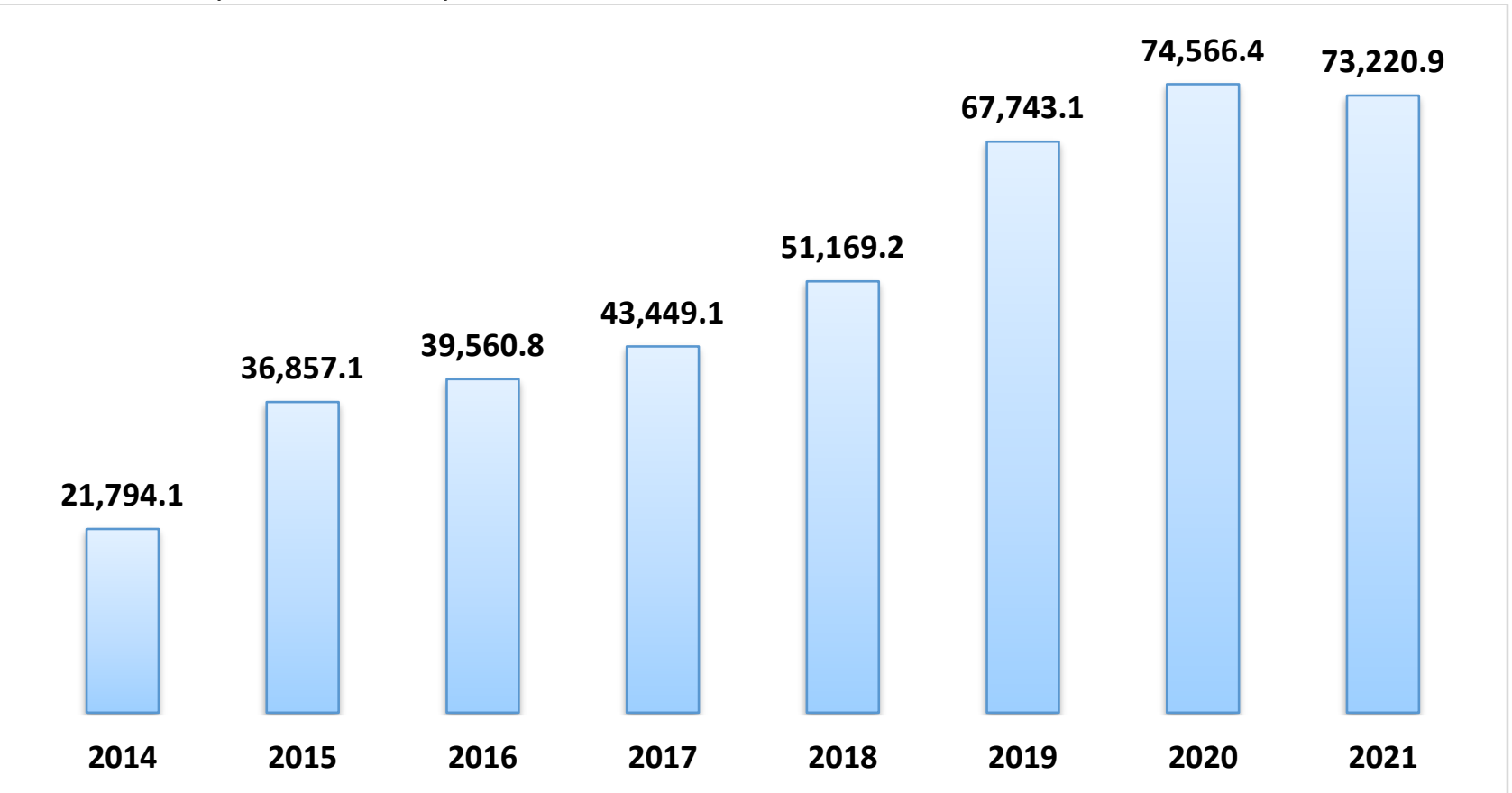

Рис. 4. Динаміка обсягів видатків на утримання Збройних Сил України 2014-2021 роках (млн. грн) [11-18)

Отже, на утримання 3С України впродовж останніх восьми років виділяється понад $60 \%$ від загального бюджету Міністерства оборони. У 2020 році цей показник становив 63,1 \% від загального бюджету Міністерства оборони та був найбільшим у досліджуваному періоду.

Аналіз розподілу ресурсів за видатками засвідчує, що основний їх обсяг зосереджений на утриманні ЗС України, тобто має місце так званий бюджет "проїдання".

Як показує світова практика, розподіл видатків на розвиток збройних сил має відбуватись таким чином: 40\% - утримання збройних сил, 20\% - підготовка збройних сил, $40 \%$ - розвиток озброєння та військової техніки.

Для вирішення цієї проблеми указом Президента України №121/2021 про рішення Ради національної безпеки і оборони України від 25 березня 2021 року “Про Стратегію воєнної безпеки України" визначено принципи, пріоритетні цілі, завдання та механізми забезпечення життєво-важливих інтересів держави від зовнішніх і внутрішніх загроз.

Беручи до уваги положення цього документа в частині ресурсного задоволення потреб оборони України, здійснено всебічний огляд та доцільності основних заходів, щоб забезпечити відповідність національної безпеки у військовій сфері заходам та 
завданням певних функцій, пріоритетів, концепцій, процедур та планів тощо.

Основними завданнями у стратегії визначені:

оснащення підрозділів 3С України та інших сил оборони найновішою зброєю, військовою та спеціальною технікою, а також забезпечувати ракетами та боєприпасами, враховуючи можливості оборонної промисловості, та поступово збільшувати кошти для задоволення потреб оборони України, збільшити можливості імпорту та залучення інвестиції. У планах придбання деяких високотехнологічних систем озброєння, військової та спеціальної техніки за кордоном, але потрібні додаткові кошти;

визначення фінансового ресурсу, необхідного 3С України та іншим видам сил оборони, визначатиметься із застосуванням сучасних методів оборонного планування та управління оборонними ресурсами 3 урахуванням можливостей державного бюджету для забезпечення належного утримання існуючих проектів та реалізації пріоритетних проектів із тривалим періодом;

усунення зайвих та застарілих спроможностей, впровадження енергозберігаючих

технологій, вдосконалення структури персоналу та раціональне управління, ефективне та прозоре використанням ресурсів та зменшене вивільнення додаткових оборонних ресурсів для розвитку сил оборони. Зменшення ризику корупції.

Також, важливим ресурсом для ЗС України та інших складових сил оборони й надалі залишатиметься міжнародна технічна допомога та підтримка країн-партнерів 3 питань військової освіти та навчання військ (сил), вдосконалення систем управління, автоматизації, логістики, медицини та забезпечення військового розвитку [22].

Реальні та науково-обґрунтовані напрями зниження витрат на оборону можна встановити лише на основі глибокого наукового аналізу всього спектра умов та факторів, що мають впливають на бойові можливості збройних сил. Це в свою чергу спонукає до посилення наукового супроводу фінансового забезпечення державних видатків на національну оборону, що дозволе подолати зазначені негативні тенденції у сфері фінансування потреб МО України.

\section{Висновки}

Аналіз динаміки та структури видатків на потреби МО України дає змогу узагальнити основні проблеми, які мають місце у сфері фінансового забезпечення МО України:

рівень наявного фінансового забезпечення потреб оборони не дає змоги належним чином зосередитись безпосередньо на розвитку, більша частина виділеного фінансового ресурсу спрямована на утримання особового складу;

недосконалість законодавства у сфері державних закупівель за напрямом забезпечення обороноздатності;

недосконалість бюджетного процесу, що проявляється, у тому числі з огляду на високу мінливість затверджених планів асигнувань, що викликано внесенням постійних змін та мінливості орієнтовних показників видатків; високий рівень корупції в Україні (за підсумками 2020 року Україна займає 117 місце зі 180 країн за індексом сприйняття корупції);

недосконалість системи управління.

Для подолання зазначених негативних тенденцій та проблем у сфері фінансування МО України в Україні необхідно забезпечити комплексне дослідження проблематики у предметній сфері, провести аналіз передового досвіду провідних країн світу щодо вирішення складних проблем у сфері підвищення обороноздатності, проаналізувати фактори негативного впливу на функціонування системи ресурсного забезпечення потреб оборони та виробити науково обґрунтовані рішення щодо протидії їх впливу. 
1. Світова гібридна війна: український фронт : монографія / за заг. Ред. В. П. Горбуліна. Харків : Фоліо, 2017. - 496 с.

2. Обґрунтування системи показників для оцінювання ефективності витрат на утримання i розвиток збройних Сил України в інтересах забезпечення оборонної достатності держави на короткостроковий період. Лобанов, А. А.; Троцько, В. В.; Черненко, А. Д. Збірник наукових праць Центру воєнностратегічних досліджень нуОу імені Івана Черняховського, 2017, 1-59: 41-47.

3. Використання системи ключових показників при оцінці фінансового забезпечення Збройних Сил України. Руденська, Г. В.; Педан, Ф. П.; Ткаченко, М. В. Збірник наукових праць Центру воєнностратегічних досліджень НУОУ імені Івана Черняховського, 2017, 1-59: 48-52.

4. Планування ресурсів під час оборонного огляду. Наливайко, А. Д.; Крикун, П. М.; ПоляєВ, А. І. Збірник наукових праць Центру воєнно-стратегічних досліджень нуоу імені Івана Черняховського, 2018, 263: 57-62.

5. Аналіз стану забезпечення Збройних Сил України фінансовими ресурсами та порядок комплексного планування їх розвитку. Бойко, Р. В., Семененко, О. М., Водчиць, О. Г., Добровольський, Ю. Б., \& Абрамов, А. П. (2019). Збірник наукових праць Центру воєнно-стратегічних досліджень НуОУ імені Івана Черняховського, (1-65), 51-58.

6. Методичний підхід до прогнозування динаміки розвитку Збройних Сил України з урахуванням достатності та ефективності освоєння виділених фінансових ресурсів. Семененко, О. М., Васюхно, С. І., Бокій, В. Г., \& Бутенко, М. П. (2019). Збірник наукових праць Центру воєнностратегічних досліджень НУОУ імені Івана Черняховського, (3-67), 59-65.

7. Рекомендації щодо фінансового та економічного забезпечення потреб національної оборони під час протидії гібридній війні. Ткач, М. Я., Бойко, Р. В., Лойшин, А. А., \& Бойко, В. О. (2019). Збірник наукових праць Центру воєнностратегічних досліджень НУОУ імені Івана Черняховського, (3-67), 66-71.

8. Фінансове забезпечення Збройних Сил України: тенденції та основні шляхи реформування Левчук, О. В. Збірник наукових праць Центру воєнностратегічних досліджень НУОУ імені Івана Черняховського, 2020, 2-69: 53-64.

9. Формування підходів до оборонного планування на основі спроможностей 3 урахуванням ресурсного забезпечення. Бойко, Р. В., Леонтович, С. П., Марко, Є. І., \& Бутенко, М. П. (2020). Збірник наукових праць Центру воєнно-стратегічних досліджень нуоу імені Івана Черняховського, 62-69.

10. Про Концепцію розвитку сектору безпеки і оборони України: Указ президента України від 04.03.2016 №92/2016. URL: https://zakon.rada.gov.ua/laws/show/92/20 16/ (дата звернення: 20.04.2021).

11. Про Державний бюджет України на 2021 рік: Закон України. URL: https://zakon.rada.gov.ua/laws/show/108220/ (дата звернення: 20.04.2021).

12. Про Державний бюджет України на 2014 рік: Закон України. URL: https://zakon.rada.gov.ua/laws/show/71918/ (дата звернення: 20.04.2021).

13. Про Державний бюджет України на 2015 рік: Закон України. URL: https://zakon.rada.gov.ua/laws/show/8019/print (дата звернення: 20.04.2021).

14. Про Державний бюджет України на 2016 рік: Закон України. URL: https://zakon.rada.gov.ua/laws/show/92819/ (дата звернення: 20.04.2021).

15. Про Державний бюджет України на 2017 рік: Закон України. URL: https://zakon.rada.gov.ua/laws/show/180119/ (дата звернення: 20.04.2021).

16. Про Державний бюджет України на 2018 рік: Закон України. URL: https://zakon.rada.gov.ua/laws/show/2246- 
19/ (дата звернення: 20.04.2021).

17. Про Державний бюджет України на 2019 рік: Закон України. URL: https://zakon.rada.gov.ua/laws/show/262919/ (дата звернення: 20.04.2021).

18. Про Державний бюджет України на 2020 рік: Закон України. URL: https://zakon.rada.gov.ua/laws/show/29420/ (дата звернення: 20.04.2021).

19. Одинадцять країн-членів НАТО досягли цільового показника щодо оборонних видатків URL: https://www.dw.com/uk/11krain-chleniv-nato-dosiahly-tsilovohopokaznyka-shchodo-oboronnykh-vydatkiv/a56890484.

20. Ranking total annual defense spending budget capability by country, from highest to lowest. Defense Spending by Country (2021). URL:

https://www.globalfirepower.com/defensespending-budget.php

21. Можливості оборонно-промислового комплексу України в системі національної безпеки. Аналітична записка. URL: http://old2.niss.gov.ua/articles/251/

22. Про Стратегію воєнної безпеки України: Указ президента України №121/2021 від 25 березня 2021 року. URL: https://www.president.gov.ua/documents/1 212021-37661

23. Індекс сприйняття корупції-2020. Трансперенсі Інтернешнл Україна. URL: http://cpi.ti-ukraine.org/\#/ (дата звернення 12.03.2021).

\title{
Финансирование Министерства обороны Украины как фактор влияния на систему ресурсного обеспечения нужд обороны
}

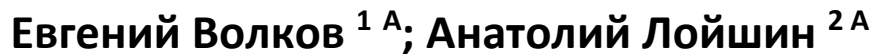 \\ ${ }^{1}$ Corresponding author: начальник учебной лаборатории, e-mail: evgeniyvolkov2231@gmail.com \\ 2 доктор философии, старший преподаватель, e-mail: aloishyn@gmail.com, ORCID: 0000-0003-2769-9336
}

А Национальный университет обороны Украины имени Ивана Черняховского, пр-кт Воздухофлотский. 28 г. Киев, 03049, Украина

\begin{abstract}
Аннотация
Результаты исследования вызывают интерес у ученых и управленцев, которые занимаются проблематикой всестороннего обеспечения потребностей обороны Украины. В условиях вооруженной агрессии Российской Федерации на востоке Украины и временной аннексии АР Крым обеспечениу неотложных нужд обороны Украины является высшим приоритетом государственной политики. Интеграция Украины в европейское пространство и попытки приобрести долгожданного членства в НАТО требует пересмотра и усовершенствования механизмов обеспечения национальной безопасности Украины, в том числе, ресурсного обеспечения. Ключевым вопросом статьи является осуществление анализа динамики расходов из государственного бюджета на нужды Министерства обороны Украины в условиях продолжающейся агрессии со стороны РФ и направления их использования. Неотъемлемым аспектом в процессе изучения данной тематики стал анализ затрат на развитие, закупку, модернизацию и ремонт вооружения, военной техники, средств, оборудования и динамики объемов расходов на содержание Вооруженных Сил Украины. Приведена динамика показателей номинального ВВП к необходимости оборонных расходов. Предложенные минимальные шаги для совершенствования существующего механизма финансового обеспечения нужд оборонного, оборонно-промышленного комплекса, создания эффективной системы управления в кризисный период. Проведенный в статье анализ позволил идентифицировать имеющиеся пробелы бюджетного процесса, проявляются за счет нестабильно ориентировочных показателей расходов, изменчивости утвержденных планов ассигнований, в которые вносятся постоянные изменения. Подтверждена необходимость в распределении расходов на
\end{abstract}


нужды соответствии с лучшими мировыми практиками. Ключевым вопросом в контексте проблематики исследования выделено длительную экономический и политический кризис и наличие длительной борьбы с коррупцией.

Ключевые слова: государственный бюджет, расходы на оборону, финансовое обеспечение потребностей Вооруженных Сил Украины, вооружение и военная техника.

\title{
Financing the Ministry of Defense of Ukraine as a factor to impact for the system of resource provision
}

\author{
Evgeniy Volkov ${ }^{1}$ A; Anatolii Loishyn ${ }^{1 \mathrm{~A}}$ \\ ${ }^{1}$ Corresponding author: head of educational laboratory, e-mail: evgeniyvolkov2231@gmail.com \\ ${ }^{2}$ PhD, Senior lector of Department of financial support, e-mail: aloishyn@gmail.com, ORCID: 0000-0003-2769-9336

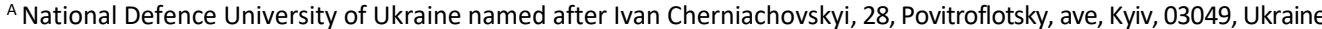

\begin{abstract}
The article is of interest to scientists and managers who are concerned with the comprehensive provision of Ukraine's defense needs. In the context of the armed aggression of the Russian Federation in eastern Ukraine and the temporary annexation of the Autonomous Republic of Crimea, ensuring the urgent needs of Ukraine's defense is the highest priority of state policy. Ukraine's integration into the European space and its efforts to gain long-awaited NATO membership require a review and improvement of Ukraine's national security mechanisms, including resource provision. The key issue of the article is the analysis of the dynamics of expenditures from the state budget for the needs of the Ministry of Defense of Ukraine in the context of ongoing aggression by the Russian Federation and the directions of their use. An integral aspect in the process of studying this topic was the analysis of costs for the development, purchase, modernization and repair of weapons, military equipment, tools, equipment and the dynamics of expenditures for the maintenance of the Armed Forces of Ukraine. The dynamics of nominal GDP indicators to the need for defense expenditures is also presented. The minimum steps for improvement of the existing mechanism of financial maintenance of needs of a defense, defense-industrial complex, and creation of effective system of management in the crisis period are offered. The analysis conducted in the article allowed to identify the existing gaps in the budget process, which is manifested in the variability of the approved allocation plans in which constant changes are made, volatile indicators of expenditures. The key issues in the context of the study are the long-term economic and political crisis and the long-term fight against corruption.
\end{abstract}

Keywords: state budget, defense expenditures, financial support for the needs of the Armed Forces of Ukraine, armaments and military equipment.

\section{References}

1. Svitova hibrydna viyna: ukrayins'kyy front : monohrafiya / za zah. Red. [a monograph / for general]. V. P. Horbulina. - Kharkiv : Folio, 2017. $-496 \mathrm{~s}$.

2. Obgruntuvannya systemy pokaznykiv dlya otsinyuvannya efektyvnosti vytrat na utrymannya i rozvytok Zbroynykh Syl Ukrayiny $v$ interesakh zabezpechennya oboronnoyi dostatnosti derzhavy na korotkostrokovyy period. [Substantiation of the system of indicators for estimating the efficiency of expenses for the maintenance and development of the Armed Forces of Ukraine in the interests of ensuring the defense sufficiency of the state for the short term]. Lobanov, A. A., Trots'ko, V. V., Chernenko, A. D. Zbirnyk naukovykh prats' Tsentru voyenno-stratehichnykh doslidzhen' NUOU, 2017, 1-59: 41-47.

3. Vykorystannya systemy klyuchovykh pokaznykiv pry otsintsi finansovoho zabezpechennya Zbroynykh Syl Ukrayiny [The 
use of the system of key indicators in assessing the financial support of the Armed Forces of Ukraine]Rudens'ka, H. V., Pedan, F. P., Tkachenko, M. V. Zbirnyk naukovykh prats' Tsentru voyenno-stratehichnykh doslidzhen' NUOU, 2017, 1-59: 48-52

4. Planuvannya resursiv pid chas oboronnoho ohlyadu [Resource planning during the defense review]. Nalyvayko, A. D., Krykun, P. M., Polyayev, A. I. Zbirnyk naukovykh prats' Tsentru voyenno-stratehichnykh doslidzhen' NUOU, 2018, 2-63: 57-62.

5. Analiz stanu zabezpechennya Zbroynykh Syl Ukrayiny finansovymy resursamy ta poryadok kompleksnoho planuvannya yikh rozvytku. [ Analysis of the state of providing the Armed Forces of Ukraine with financial resources and the procedure for comprehensive planning of their development.].Boyko, R. V., Semenenko, O. M., Vodchyts', O. H., Dobrovol's'kyy, YU. B., \& Abramov, A. P. Zbirnyk naukovykh prats' Tsentru voyenno-stratehichnykh doslidzhen' NUOU, (1-65), 51-58.

6. Metodychnyy pidkhid do prohnozuvannya dynamiky rozvytku Zbroynykh Syl Ukrayiny z urakhuvannyam dostatnosti ta efektyvnosti osvoyennya vydilenykh finansovykh resursiv [Methodical approach to forecasting the dynamics of development of the Armed Forces of Ukraine taking into account the adequacy and efficiency of the development of allocated financial resources].Semenenko, O. M., Vasyukhno, S. I., Bokiy, V. H., \& Butenko, M. P. Zbirnyk naukovykh prats' Tsentru voyenno-stratehichnykh doslidzhen' NUOU, (3-67), 59-65.

7. Rekomendatsiyi shchodo finansovoho ta ekonomichnoho zabezpechennya potreb natsional'noyi oborony pid chas protydiyi hibrydniy viyni.[Recommendations for financial and economic support of national defense needs in combating hybrid warfare]. Tkach, M. YA., Boyko, R. V., Loyshyn, A. A., \& Boyko, V. O. Zbirnyk naukovykh prats' Tsentru voyenno-stratehichnykh doslidzhen' NUOU, (3-67), 66-71.

8. Finansove zabezpechennya Zbroynykh Syl Ukrayiny: tendentsiyi ta osnovni shlyakhy reformuvannya [Financial support of the Armed Forces of Ukraine: trends and main ways of reforming]. Levchuk, O. V. Zbirnyk naukovykh prats' Tsentru voyennostratehichnykh doslidzhen' NUOU, 2020, 269: 53-64.

9. Formuvannya pidkhodiv do oboronnoho planuvannya na osnovi spromozhnostey $z$ urakhuvannyam resursnoho zabezpechennya [Formation of approaches to defense planning based on capabilities, taking into account resource provision]. Boyko, R. V., Leontovych, S. P., Marko, YE. I., \& Butenko, M. P. Zbirnyk naukovykh prats' Tsentru voyenno-stratehichnykh doslidzhen' NUOU imeni Ivana Chernyakhovs'koho, 62-69.

10. Pro Kontseptsiyu rozvytku sektoru bezpeky i oborony Ukrayiny: [On the Concept of Development of the Security and Defense Sector of Ukraine]: Ukaz prezydenta Ukrayiny vid 04.03.2016 №92/2016. Available from: https://zakon.rada.gov.ua/laws/show/92/20 16/. (data zvernennya: 20.04.2021).

11. Pro Derzhavnyy byudzhet Ukrayiny na 2021 rik: [On the State Budget of Ukraine for 2021] : Zakon Ukrayiny: Available from: https://zakon.rada.gov.ua/laws/show/108220/print (data zvernennya: 20.04.2021.

12. Pro Derzhavnyy byudzhet Ukrayiny na 2014 rik: [On the State Budget of Ukraine for 2014] : Zakon Ukrayiny: Available from: https://zakon.rada.gov.ua/laws/show/71918/print (data zvernennya: 20.04.2021).

13. Pro Derzhavnyy byudzhet Ukrayiny na 2015 rik: [On the State Budget of Ukraine for 2015] : Zakon Ukrayiny. Available from: https://zakon.rada.gov.ua/laws/show/8019/print (data zvernennya: 20.04.2021)

14. Pro Derzhavnyy byudzhet Ukrayiny na 2016 rik: [On the State Budget of Ukraine for 2016] : Zakon Ukrayiny. Available from: https://zakon.rada.gov.ua/laws/show/92819/print (data zvernennya: 20.04.2021).

15. Pro Derzhavnyy byudzhet Ukrayiny na 2017 rik: [On the State Budget of Ukraine for 2017]: Zakon Ukrayiny. Available from: https://zakon.rada.gov.ua/laws/show/180119/print (data zvernennya: 20.04.2021).

16. Pro Derzhavnyy byudzhet Ukrayiny na 2018 
rik: [On the State Budget of Ukraine for 2018]: Zakon Ukrayiny. Available from: https://zakon.rada.gov.ua/laws/show/224619/print (data zvernennya: 20.04.2021).

17. Pro Derzhavnyy byudzhet Ukrayiny na 2019 rik: [On the State Budget of Ukraine for 2019]: Zakon Ukrayiny. Available from: https://zakon.rada.gov.ua/laws/show/262919/print (data zvernennya: 20.04.2021).

18. Pro Derzhavnyy byudzhet Ukrayiny na 2020 rik: [On the State Budget of Ukraine for 2020]: Zakon Ukrayiny. Available from: https://zakon.rada.gov.ua/laws/show/29420/print (data zvernennya: 20.04.2021).

19. Odynadtsyat' krayin-chleniv NATO dosyahly tsil'ovoho pokaznyka shchodo oboronnykh vydatkiv [Eleven NATO members have reached the target for defense spending]. Available from: https://www.dw.com/uk/11krain-chleniv-nato-dosiahly-tsilovohopokaznyka-shchodo-oboronnykh-vydatkiv/a$\underline{56890484 .}$

20. Ranking total annual defense spending budget capability by country, from highest to lowest. Defense Spending by Country (2021). Available from: https://www.globalfirepower.com/defensespending-budget.php

21. Mozhlyvosti oboronno-promyslovoho kompleksu Ukrayiny v systemi natsional'noyi bezpeky [Possibilities of the defenseindustrial complex of Ukraine in the system of national security]. Analitychna zapyska. Available from: http://old2.niss.gov.ua/articles/251/

22. Pro Stratehiyu voyennoyi bezpeky Ukrayiny: [On the Strategy of Military Security of Ukraine]: Ukaz prezydenta Ukrayiny №121/2021 vid 25 bereznya 2021 roku. Available from: https://www.president.gov.ua/documents/1 212021-37661

23. Indeks spryynyattya koruptsiyi-2020 [Corruption Perceptions Index 2020]. Transperensi Interneshnl Ukrayina. Available from: http://cpi.ti-ukraine.org/\#/ (data zvernennya 12.03.2021). 